\title{
Physician global assessments or blood tests do not predict mucosal disease activity in ulcerative colitis
}

\author{
Mayur Brahmania MD, Charles N Bernstein MD
}

M Brahmania, CN Bernstein. Physician global assessments or blood tests do not predict mucosal disease activity in ulcerative colitis. Can J Gastroenterol Hepatol 2014;28(6):325-329.

BACKGROUND: Mucosal healing has been proposed as the therapeutic end point in the treatment of patients with ulcerative colitis (UC).

OBJECTIVE: To investigate the relationship between physician global assessment (PGA) and laboratory blood tests (complete blood count, ferritin, C-reactive protein, albumin) and endoscopic findings in UC to determine whether they could be adequate surrogates for endoscopy.

METHODS: A retrospective chart review of patients known to have UC from July 2008 to November 2012 was performed at the Health Sciences Centre, Winnipeg, Manitoba. Patients included individuals with UC who underwent colonoscopy within one month of clinic assessment. Blood tests were standard at the time of colonoscopy. Patients presenting through the emergency department, those with colonoscopies performed outside the authors' institution, or whose colonoscopies and clinical assessments were undertaken more than one month apart were excluded. The PGA was used to determine disease activity in patients before colonoscopy. The Ulcerative Colitis Endoscopic Index of Severity, a validated scoring system to rate endoscopic disease severity in ulcerative colitis, was adapted.

RESULTS: A total of 154 patients (mean [ \pm SD] age $44 \pm 15.7$ years) with UC were identified including $82(53 \%)$ men. Mean hemoglobin level was $139 \mathrm{~g} / \mathrm{L}$, mean platelet level was $296 \times 10^{9} / \mathrm{L}$, mean ferritin level was $102 \mu \mathrm{g} / \mathrm{L}$, mean C-reactive protein level was $10 \mathrm{mg} / \mathrm{L}$ and mean albumin level was $40 \mathrm{~g} / \mathrm{L}$. Using endoscopy as the 'gold standard' for assessing UC activity (moderate-severe), abnormalities in laboratory parameters and PGA were both highly specific but not sensitive for identifying individuals with at least moderately active endoscopic disease. The PGA had higher positive and negative predictive values than the laboratory parameters.

CONCLUSION: Neither blood tests nor PGA could replace endoscopy for assessing mucosal healing. When patients experienced active symptoms and abnormal serum markers, they were highly likely to have abnormal endoscopy. However, inactive symptoms or normal laboratory values did not preclude having active endoscopic disease.

Key Words: Mucosal healing; Physician global assessment; Ulcerative colitis; Ulcerative Colitis Endoscopic Index of Severity (UCEIS)

Tlcerative colitis (UC) is an inflammatory disorder of the gastrointestinal tract characterized by radiological, endoscopic and histological changes. An assessment of disease activity and extent can help direct therapy and, potentially, also assess for dysplasia (1). For Crohn disease, the Crohn's Disease Activity Index, a predominately subjective index, remains the main outcome measure used to assess disease activity in clinical trials. For UC, there has been increasing interest in using endoscopic scoring scales to assess endoscopic activity as the critical outcome in clinical trials. Currently, there is no consensus on a validated scale to define disease activity in UC; however, the Mayo score, which is a combination of clinical and endoscopic disease

\author{
Les évaluations globales des médecins ou les \\ hémocultures ne prédisent pas l'activité de la colite \\ ulcéreuse sur les muqueuses
}

HISTORIQUE : La guérison des muqueuses est proposée comme indicateur de résultat thérapeutique pour le traitement des patients atteints d'une colite ulcéreuse (CU).

OBJECTIF : Examiner la relation entre l'évaluation globale du médecin (ÉGM), ainsi que les analyses sanguines en laboratoire (hémogramme, ferritine, protéine C-réactive, albumine), et les résultats endoscopiques de la CU pour déterminer si elles peuvent remplacer convenablement l'endoscopie.

MÉTHODOLOGIE: Entre juillet 2008 et novembre 2012, les chercheurs ont effectué un examen rétrospectif des dossiers des patients qu'on savait atteints de CU au Health Sciences Centre de Winnipeg, au Manitoba. Les patients incluaient des personnes atteintes de CU qui avaient subi une coloscopie dans le mois suivant l'évaluation clinique. Les hémocultures étaient standards au moment de la coloscopie. Les patients qui s'étaient présentés par l'urgence et ceux qui avaient subi une coloscopie à l'extérieur de l'établissement des auteurs ou dont la coloscopie et l'évaluation clinique avaient été effectuées à plus d'un mois d'écart étaient exclus. L'ÉGM a permis de déterminer l'activité de la maladie chez les patients avant la coloscopie. Les chercheurs ont adopté l'indice endoscopique de gravité de la CU, un système de pointage validé pour évaluer la gravité endoscopique de la CU.

RÉSULTATS : Au total, 154 patients (âge moyen [ \pm ÉT] de 44 15,7 ans) atteints de CU ont été retenus, y compris 82 hommes (53\%). Le taux d'hémoglobine moyen s'établissait à $139 \mathrm{~g} / \mathrm{L}$, le taux plaquettaire moyen, à $296 \times 10^{9} / \mathrm{L}$, le taux de ferritine moyen, à $102 \mu \mathrm{g} / \mathrm{L}$, le taux de protéine C-réactive moyen, à $10 \mathrm{mg} / \mathrm{L}$ et le taux d'albumine moyen, à $40 \mathrm{~g} / \mathrm{L}$. Si on utilise l'endoscopie comme norme de référence pour évaluer l'activité de la CU (modérée à grave), les anomalies dans les paramètres de laboratoire et l'ÉGM étaient tous deux hautement spécifiques, mais pas sensibles pour déterminer les individus atteints d'une maladie au moins modérément active à l'endoscopie. L'ÉGM avait des valeurs prédictives positives et négatives plus élevées que les paramètres de laboratoire.

CONCLUSION : Ni les hémocultures ni les ÉGM ne pouvaient remplacer l'endoscopie pour évaluer la guérison des muqueuses. Lorsque les patients ressentaient des symptômes actifs et présentaient des marqueurs sériques anormaux, ils étaient hautement susceptibles d'obtenir une endoscopie anormale. Cependant, les symptômes inactifs ou les valeurs de laboratoire normales n'excluaient pas une maladie active à l'endoscopie.

parameters (or the modified Mayo score, which only uses clinical parameters), has been widely adopted for clinical trials (2). However, clinicians have not adopted these indexes or scores for routine clinical use. Blood tests, such as C-reactive protein (CRP), hemoglobin ( $\mathrm{Hg}$ ), platelet (plt) count, and ferritin and albumin levels, are also used as markers of disease activity; however, abnormalities in these measures may also indicate other medical problems and have been shown to correlate poorly with disease activity $(3,4)$. Endoscopy is currently the gold standard to assess for inflammatory changes in the colonic mucosa. However, with resource constraints, risks with invasive procedures and the discomfort with colonoscopy, physicians often rely on

Department of Internal Medicine, Division of Gastroenterology, University of Manitoba Inflammatory Bowel Disease Clinical and Research Centre,

Winnipeg, Manitoba

Correspondence: Dr Charles N Bernstein, 804F-175 McDermot Avenue, Winnipeg, Manitoba R3E 3P4. Telehone 204-789-3369,

fax 204-789-3972, e-mail charles.bernstein@med.umanitoba.ca

Received for publication January 12, 2014. Accepted April 14, 2014 
TABLE 1

Ulcerative Colitis Endoscopic Index of Severity (UCEIS)

\begin{tabular}{|c|c|c|}
\hline $\begin{array}{l}\text { Descriptor (score of } \\
\text { most severe lesions) }\end{array}$ & Scale anchor points & Definition \\
\hline \multirow[t]{3}{*}{ Vascular pattern } & Normal (1) & $\begin{array}{l}\text { Normal vascular pattern with arborization of capillaries clearly defined, or with blurring or patchy } \\
\text { loss of capillary margins }\end{array}$ \\
\hline & Patchy obliteration (2) & Patchy obliteration of vascular pattern \\
\hline & Obliterated (3) & Complete obliteration of vascular pattern \\
\hline \multirow[t]{4}{*}{ Bleeding } & None (1) & No visible blood \\
\hline & Mucosal (2) & $\begin{array}{l}\text { Some spots or streaks of coagulated blood on the surface of the mucosa ahead of the scope, } \\
\text { which can be washed away }\end{array}$ \\
\hline & Luminal mild (3) & Some free liquid blood in the lumen \\
\hline & Luminal moderate or severe (4) & $\begin{array}{l}\text { Frank blood in the lumen ahead of endoscope or visible oozing from mucosa after washing } \\
\text { intraluminal blood, or visible oozing from a hemorrhagic mucosa }\end{array}$ \\
\hline \multirow[t]{4}{*}{ Erosions and ulcers } & None (1) & Normal mucosa, no visible erosions or ulcers \\
\hline & Erosions (2) & Tiny $(\leq 5 \mathrm{~mm})$ defects in the mucosa, of a white or yellow colour with a flat edge \\
\hline & Superficial ulcer (3) & $\begin{array}{l}\text { Larger ( }>5 \mathrm{~mm}) \text { defects in the mucosa, which are discrete fibrin-covered ulcers when compared } \\
\text { with erosions, but remain superficial }\end{array}$ \\
\hline & Deep ulcer (4) & Deeper excavated defects in the mucosa, with a slightly raised edge \\
\hline
\end{tabular}

UCEIS = sum of scores, which accounts for $92 \%$ of the variance between observers in the overall assessment of endoscopic severity

clinical acumen (ie, a physician global assessment [PGA]) along with laboratory markers to determine disease activity. It has been proposed that endoscopic mucosal healing $(\mathrm{MH})$ be used as the primary end point in the treatment of UC to judge response to medical treatment, to predict the course of the disease and to prevent complications (5-10). How to optimally achieve $\mathrm{MH}$ or the necessity for achieving $\mathrm{MH}$ in asymptomatic patients is currently unclear. In the present study, we investigated the relationship between PGA and readily available blood tests (complete blood count, ferritin, CRP, albumin) to endoscopic findings in UC. We hypothesized the PGA or usual blood tests would highly correlate with endoscopic findings and, hence, would be sufficient to guide clinicians in patient management.

\section{METHODS}

Colonoscopy reports of all patients known to have UC from July 2008 to November 2012 from a single gastroenterology practice at the Health Sciences Centre, Winnipeg, Manitoba, a tertiary care referral centre for inflammatory bowel disease (IBD), were retrospectively reviewed. Patients included individuals with UC having bloodwork (complete blood count, CRP, ferritin, albumin) within one week of visit and undergoing colonoscopy after clinic assessment (within one month). Cut-off values for bloodwork in the analysis included Hg levels $<120 \mathrm{~g} / \mathrm{L}$ for females and $<140 \mathrm{~g} / \mathrm{L}$ for males, plt count $>4.0 \times 10^{9} / \mathrm{L}$, albumin $<33 \mathrm{~g} / \mathrm{L}$, ferritin $<20 \mu \mathrm{g} / \mathrm{mL}$ and CRP $>8 \mathrm{mg} / \mathrm{L}$, which represented abnormal values at the authors' institution. No deviations from standard care were taken (ie, patients being expedited to endoscopy). Patients presenting through the emergency room, those with colonoscopies performed outside the authors' institution, or whose colonoscopies and clinical assessments were undertaken more than one month apart were excluded. The PGA was used to determine disease activity in patients before colonoscopy and was performed at time of clinic visit. Currently, no validated PGA exists; therefore, an assessment tool based on routine questions gastroenterologists use during interviews to gauge disease activity was created. To determine a global assessment, patients were queried at each clinic visit as to the number of bowel movements, presence or absence of abdominal pain, presence of blood with defecation and objective weight loss (as determined by the clinic scale). These criteria used in the PGA are documented in all patient encounters at the authors' centre. The assessment was rated as:

1. Remission: no abdominal pain, $\leq 2$ bowel movements/day, absence of blood with defecation, and stable/no weight loss.

2. Mildly active disease: mild to moderate abdominal pain, $\leq 4$ bowel movements/day, occasional blood with defecation and objective weight loss.
3. Active symptoms: moderate to severe abdominal pain, $>4$ bowel movements/day, bloody defecation with most bowel movements and objective weight loss.

Patient disease activity was categorized based on having at least two of the four symptoms identified with each category. If they had only one symptom that moved them to a higher, more active category, it would not have changed their categorization. For example, an individual with one mild symptom and three symptoms that would have been considered to be in remission were categorized as remission. If at least two mild symptoms were present and zero or one active symptom, then they were considered to be mild. If there were at least two active symptoms they were categorized as active. For example, if a patient had mild abdominal pain (mild symptom), six bowel movements/day (active symptom), minimal blood with defecation (mild symptom) and no weight loss, they would be categorized as having 'mildly active' disease. Patients were identified through an electronic database of all persons presenting to the IBD clinic and their charts were systematically reviewed. Demographic data including age, sex and blood tests (serum $\mathrm{Hg}$, plt count, CRP, ferritin and albumin level) were collected. Patients were grouped as active (active symptoms) or mild to inactive (remission, mild) for the PGA. A total of 154 patients met the inclusion criteria for the study. An adapted form of the Ulcerative Colitis Endoscopic Index of Severity (UCEIS), a validated scoring system to rate endoscopic disease activity in UC (Table 1), was used because the UCEIS was not available during the study period. Evaluating the most diseased area on endoscopy, the following parameters were used and categorized patients into:

1. Remission: complete $\mathrm{MH}$ that could include 'footprints' of past disease such as pseudopolyps or white scars.

2. Mild disease: vascular blush or loss of vascular pattern, minimal exudates or friability.

3. Moderate disease: friability, granularity, scattered erosions and ulcers.

4. Severe disease: contiguous or deep ulcers and frank bleeding.

Similar to the PGA, the authors use a standard reporting format with all UC patients and include these elements in their colonoscopy reports in addition to pictures documenting diseased areas. Because the authors evaluated the most diseased areas, every endoscopic report included information regarding the most diseased area; the reports at their centre included the necessary variables to report a UCEIS. If there was insufficient information on the endoscopy report, the subject was excluded. The primary end point was to assess how well the PGA could assess $\mathrm{MH}$ as defined by features on endoscopy. Secondary end points included a correlation of blood tests $(\mathrm{Hg}$, plt count, CRP, 
TABLE 2

\section{Patient characteristics}

\begin{tabular}{lc}
\hline Variable & Mean outcome (except for sex) \\
\hline Male sex, \% & 53 \\
Age, years & 44 \\
Hemoglobin, g/L & 139 \\
Platelet count, $\times 10^{9} / \mathrm{L}$ & 296 \\
C-reactive protein, $\mathrm{mg} / \mathrm{L}$ & 10 \\
Ferritin, $\mu \mathrm{g} / \mathrm{L}$ & 102 \\
Albumin, g/L & 40 \\
Disease duration, years & 15 \\
\hline
\end{tabular}

ferritin and albumin) with endoscopic features. Because the present analysis was a retrospective observational study, results are presented with descriptive statistics. Mean and SD are used to report continuous variables following a normal distribution and median (range) are used to report non-normal continuous variables.

\section{RESULTS}

A total of 154 patients with UC were identified. Males comprised 53\% $(n=82)$ of the total population. The mean $( \pm$ SD) age of patients was $44 \pm 15.7$ years. The mean $\mathrm{Hg}$ level was $139 \mathrm{~g} / \mathrm{L}$, mean platelet level was $296 \times 10^{9} / \mathrm{L}$, mean ferritin level was $102 \mu \mathrm{g} / \mathrm{L}$, mean CRP level was $10 \mathrm{mg} / \mathrm{L}$ and mean albumin level was $40 \mathrm{~g} / \mathrm{L}$ (Table 2). The average disease duration was 15 years (range two to 42 years), with $82 \%$ having pancolitis and $18 \%$ having left-sided colitis (including proctosigmoiditis) as the predominant disease extent at time of diagnosis. Of the colonoscopies, $76 \%$ were performed as routine dysplasia surveillance and $24 \%$ were performed due to patient experiencing symptoms such as abdominal pain, diarrhea or bright red blood per rectum. In terms of medications used, $46 \%$ were using 5 -aminosalicylic acid products with varying doses as their predominant maintenance regimen, $22 \%$ were not on any medications, $13 \%$ were on immunomodulator therapy (azathioprine or 6-mercaptopurine), 8\% were on anti-tumour necrosis factor (Remicade [Janssen Inc, USA] or Humira [Abbott Laboratories, USA]), $2 \%$ were on methotrexate and $9 \%$ were on combination therapy (Table 3). Using endoscopy as the 'gold standard' for assessing UC activity (moderate-severe), abnormalities in laboratory parameters were highly specific ( $\mathrm{Hg} 88 \%$; albumin 97\%, ferritin 91\%, plt count $89 \%$, CRP $72 \%$ ) but not sensitive ( $\mathrm{Hg} 34 \%$; albumin 7\%, ferritin $23 \%$, plt count $16 \%$, CRP 28\%) for identifying individuals with at least moderately active endoscopy. The PGA was comparably sensitive $(30 \%)$ and specific $(97 \%)$ as laboratory parameters but with higher positive $(83 \%)$ and negative $(74 \%)$ predictive values (Table 4$)$. Also conducted was a subgroup analysis of patients experiencing symptoms, either 'mild' or 'active' according to the PGA, excluding those considered to be in remission, and found similarly high specificities for laboratory parameters $(\mathrm{Hg} 91 \%$, albumin $92 \%$, ferritin $72 \%$, plt count $84 \%$, CRP $86 \%$ ) but still low sensitivities ( $\mathrm{Hg} 45 \%$, albumin $12 \%$, ferritin 24\%, plt count 23\%, CRP 36\%). The PGA also had comparable sensitivity (48\%) and specificity $(86 \%)$ but with higher positive $(83 \%)$ and lower negative (54\%) predictive values than the when analyzing all persons including those in remission (Table 5).

\section{DISCUSSION}

Traditionally, initiation and escalation of therapy in UC has been based on severity of symptoms with the goal of alleviating those symptoms using a variety of medications (5-aminosalicylic acid, steroids, immunomodulators and biologics). However, treating symptoms alone may not be sufficient to achieve optimal long-term outcomes (eg, fewer complications and hospitalizations, and better quality of life), and targeting mucosal inflammation and associated tissue damage may be equally important. $\mathrm{MH}$ has been proposed as an optimal goal of treatment because it can correlate with hospitalizations and colectomy rates $(7-10)$. The exact definition of $\mathrm{MH}$ is unclear and has not been
TABLE 3

Ulcerative colitis characteristics

\begin{tabular}{lc}
\hline Variable & $\begin{array}{c}\text { Ulcerative colitis } \\
(\mathbf{n}=\mathbf{1 5 4})\end{array}$ \\
\hline Reason for colonoscopy (dysplasia surveillance) & 76 \\
Disease extent at diagnosis (pancolitis) & 82 \\
Medication use & \\
None & 22 \\
5-aminosalicylic acid & 46 \\
Immunomodulator (AZA/6-MP) & 13 \\
Biologic (infliximab/adalimunab) & 8 \\
Combination (AZA/infliximab) & 1 \\
Other* & 10 \\
Endoscopic severity & \\
Remission & 42 \\
Mild & 26 \\
Moderate & 26 \\
Severe & 6
\end{tabular}

Data presented as \%. ${ }^{*}$ Combination of 5-aminosalicylic acid/azathioprine (AZA), infliximab/methotrexate, methotrexate. 6-MP 6-Mercaptopurine

validated; however, the International Organization for the Study of Inflammatory Bowel Disease has proposed defining $\mathrm{MH}$ in $\mathrm{UC}$ as the absence of friability, blood, erosions and ulcers in all visualized segments of gut mucosa (12). Whether $\mathrm{MH}$ should represent the complete absence of any characteristic endoscopic lesions or simply marked improvement in the severity of previously noted lesions is an issue that is evolving. Currently, no guidelines have been developed to determine the optimal timing for follow-up endoscopy to identify $\mathrm{MH}$ (13). Endoscopic evaluation can be time consuming and costly, while incurring small but real risks for adverse events. Froslie et al (7) documented the important role of $\mathrm{MH}$ in monitoring treatment effectiveness and long-term disease outcome during a five-year follow-up period. In their study, $50 \%$ of patients with UC had confirmed $\mathrm{MH}$ after one year and had a significantly lower risk of future colectomy than patients without $\mathrm{MH}(\mathrm{P}=0.02)$. Several other long-term benefits of $\mathrm{MH}$ have been identified, including decreased need for surgery and hospitalization, lower steroid use, decreased risk of colorectal cancer and higher remission rates (5-10).

The PGA or, less formally, a clinician's impression of the patient's disease status, is typically used to guide therapeutic decisions. Many activity indexes have been used indirectly to assess clinical status. Common indexes, such as Truelove and Witts, Powell-Tuck, Ulcerative Colitis Disease Activity Index and Mayo Disease Activity Index, use a combination of symptoms, signs and sigmoidoscopy to assess clinical disease; however, none of these scales have been validated specifically for $\mathrm{MH}(14-20)$. Attempts are now underway to develop a validated endoscopic score that may be universally adopted such as the UCEIS developed by Travis et al (11). In our study, we found the PGA to correlate poorly with active endoscopic disease; however, it was marginally better than the blood tests routinely ordered by gastroenterologists to estimate disease activity status. When the PGA or any of the blood tests are abnormal, there was a high likelihood the endoscopic findings were at least moderately active. When the PGA or blood tests were normal, however, they missed many subjects who had active endoscopic disease.

Noninvasive quantitative indexes have been developed in UC based on symptoms and blood tests $(\mathrm{Hg}$, albumin and erythrocyte sedimentation rate) that have correlated well with the Truelove and Witts classification (mild, moderate, severe) (21). However, a previous study involving 82 patients showed that CRP is only raised $50 \%$ of the time in active UC but does aid in differentiating IBD from chronic abdominal pain $(22,23)$. In addition, blood tests such as $\mathrm{Hg}$, plt 
TABLE 4

Association of abnormal laboratory data with endoscopy as the gold standard (moderate-severe disease)

\begin{tabular}{|c|c|c|c|c|c|c|}
\hline & $\begin{array}{c}\text { Hemoglobin } \\
\text { (<120 g/L females, } \\
<140 \mathrm{~g} / \mathrm{L} \text { males })\end{array}$ & $\begin{array}{l}\text { Albumin } \\
(<33 \mathrm{~g} / \mathrm{L})\end{array}$ & $\begin{array}{c}\text { Ferritin } \\
(<20 \mu \mathrm{g} / \mathrm{mL})\end{array}$ & $\begin{array}{c}\text { Platelet count } \\
\left(>4.0 \times 10^{9} / \mathrm{L}\right)\end{array}$ & $\begin{array}{c}\text { C-reative protein } \\
\text { (>8 mg/L) }\end{array}$ & $\begin{array}{c}\text { Physician global } \\
\text { assessment }\end{array}$ \\
\hline Sensitivity & 34 & 7 & 23 & 16 & 28 & 30 \\
\hline Positive predictive value & 57 & 60 & 63 & 44 & 47 & 83 \\
\hline Negative predictive value & 73 & 62 & 65 & 66 & 53 & 74 \\
\hline
\end{tabular}

Data presented as \%

TABLE 5

Association of abnormal laboratory data with endoscopy as the gold standard (moderate-severe disease) excluding patients in remission according to physician global assessment

\begin{tabular}{|c|c|c|c|c|c|c|}
\hline & $\begin{array}{c}\text { Hemoglobin } \\
\text { (<120 g/L females, } \\
<140 \mathrm{~g} / \mathrm{L} \text { males) }\end{array}$ & $\begin{array}{l}\text { Albumin } \\
(<33 \mathrm{~g} / \mathrm{L})\end{array}$ & $\begin{array}{c}\text { Ferritin } \\
(<20 \mu \mathrm{g} / \mathrm{mL})\end{array}$ & $\begin{array}{l}\text { Platelet count } \\
\left(>4.0 \times 10^{9} / \mathrm{L}\right)\end{array}$ & $\begin{array}{l}\text { C-reative protein } \\
\text { (>8 mg/L) }\end{array}$ & $\begin{array}{c}\text { Physician global } \\
\text { assessment }\end{array}$ \\
\hline Sensitivity & 45 & 12 & 24 & 23 & 36 & 48 \\
\hline Specificity & 91 & 92 & 72 & 84 & 75 & 86 \\
\hline Positive predictive value & 88 & 75 & 67 & 70 & 78 & 83 \\
\hline Negative predictive value & 54 & 33 & 30 & 40 & 33 & 54 \\
\hline
\end{tabular}

Data presented as \%

counts, ferritin levels and CRP can serve as markers to assess disease activity, but in the case of a hospitalized or sick patient, low or high laboratory markers can reflect an acute or chronic inflammatory process such as infection, malabsorption, trauma, cancer or the disease itself giving false positive/negative results. Unfortunately, none of these disease activity indexes, invasive or noninvasive, endoscopic or histological, has been formally well validated in terms of reflecting the evolution of the disease in the long term.

Our analysis highlights a few key points. First, physicians are not adequately able to predict endoscopic disease with reasonable sensitivity for UC based on their PGA or the 'usual' blood tests that are ordered. However, abnormal PGA or laboratory parameters do signal active endoscopic disease. The main limitation of our study was that it was retrospective in design, with all of the biases of retrospectively grading endoscopy scores and PGA. That a single physician performed all of the endoscopy and had a uniform pattern of assessment, including clinical details during the assessment, was a strength of the study; however, a single physician's practice limits the external validity of the results. Additionally, most patients underwent routine screening endoscopy $(76 \%)$ and were not being assessed for acutely active symptoms.

\section{CONCLUSION}

A combination of serum markers ( $\mathrm{Hg}$, plt count, and ferritin, albumin and CRP levels), and clinical symptoms (PGA) in a comprehensive activity index may be a promising, noninvasive and, possibly, cost-effective approach to evaluate patients with UC; however, individually cannot replace endoscopy for assessing $\mathrm{MH}$. Nonetheless, when patients experienced active symptoms and abnormal serum markers, they were highly likely to have abnormal endoscopy in our study. However, inactive symptoms or normal laboratory values did not preclude having active endoscopic disease. It is possible that other blood markers or fecal markers of inflammation may add to the PGA to serve as better surrogate markers of $\mathrm{MH}$ in future prospective studies involving adult patients with UC.

DISCLOSURES: The authors have no financial disclosures or conflicts of interest to declare.

\section{REFERENCES}

1. Danese S, Fiocchi C. Ulcerative colitis. N Engl J Med 2011;365:1713-25.

2. Stange EF, Travis SP, Vermeire S, et al. European evidence-based consensus on the diagnosis and management of ulcerative colitis: Definitions and diagnosis. J Crohns Colitis 2008;2:1-23.

3. Fagan EA, Dyck RF, Maton PN, et al. Serum levels of C-reactive protein in Crohn's disease and ulcerative colitis. Eur J Clin Invest 1982;12:351-9.

4. Lewis JD. The utility of biomarkers in the diagnosis and therapy of inflammatory bowel disease. Gastroeterology 2011;140:1817-26.

5. Rutgeerts P, Vermeire S, Van Assche G. Mucosal healing in inflammatory bowel disease: impossible ideal or therapeutic target? Gut 2007;56:453-5.

6. Peyrin-Biroulet L, Ferrante M, Magro F, et al. Results from the 2nd scientific workshop of the ECCO. I: Impact of mucosal healing on the course of inflammatory bowel disease. J Crohns Colitis 2011;5:477-83.

7. Froslie KF, Jahnsen J, Moum BA, et al. Mucosal healing in inflammatory bowel disease: Results from a Norwegian populationbased cohort. Gastroenterology 2007;133:412-22.

8. Ardizzone S, Cassinotti A, Duca P, et al. Mucosal healing predicts late outcomes after the first course of corticosteroids for newly diagnosed ulcerative colitis. Clin Gastroenterol Hepatol 2011;9:483-9.

9. Parente F, Molteni M, Marino B, et al. Are colonoscopy and bowel ultrasound useful for assessing response to short-term therapy and predicting disease outcome of moderate-to-severe forms of ulcerative colitis? A prospective study. Am J Gastroenterol 2010;105:1150-7.

10. Colombel JF, Rutgeerts P, Reinisch W, et al. Early mucosal healing with infliximab is associated with improved long-term clinical outcomes in ulcerative colitis. Gastroenterology 2011;141:1194-201.

11. Travis SP, Schnell D, Krzeski P, et al. Developing an instrument to assess the endoscopic severity of ulcerative colitis: The Ulcerative Colitis Endoscopic Index of Severity (UCEIS). Gut 2012;61:535-42.

12. D'Haens G, Sandborn WJ, Feagan BG, et al. A review of activity indices and efficacy end points for clinical trials of medical therapy in adults with ulcerative colitis. Gastroenterology 2007;132:763-86.

13. Fefferman DS, Farrell RJ. Endoscopy in inflammatory bowel disease: Indications, surveillance, and use in clinical practice. Clin Gastroenterol Hepatol 2005;3:11-24.

14. Truelove SC, Witts LJ. Cortisone in ulcerative colitis: Final report on a therapeutic trial. Br Med J 1955;2:1041-8.

15. Baron JH, Connell AM, Lennard-Jones JE. Variation between observers in describing mucosal appearances in proctocolitis. Br Med J 1964;1:89-92. 
16. Powell-Tuck J, Bown RL, Lennard-Jones JE. A comparison of oral prednisolone given as single or multiple daily doses for active proctocolitis. Scand J Gastroenterol 1978;13:833-7.

17. Sutherland LR, Martin F, Greer S, et al. 5-aminosalicylic acid enema in the treatment of distal ulcerative colitis, proctosigmoiditis, and proctitis. Gastroenterology 1987;92:1894-8.

18. Schroeder KW, Tremaine WJ, Ilstrup DM. Coated oral 5-aminosalicylic acid therapy for mildly to moderately active ulcerative colitis. A randomized study. N Engl J Med 1987;317:1625-9.

19. Rachmilewitz D. Coated mesalazine (5-aminosalicylic acid) versus sulphasalazine in the treatment of active ulcerative colitis: A randomised trial. Br Med J 1989;298:82-6.
20. Feagan BG, Greenberg GR, Wild G, et al. Treatment of ulcerative colitis with a humanized antibody to the alpha4beta7 integrin. N Engl J Med 2005;352:2499-507.

21. Seo M, Okada M, Yao T, Ueki M, Arima S, Okumura M. An index of disease activity in patients with ulcerative colitis.

Am J Gastroenterol 1992; 87:971-6.

22. Shine B, Berghouse L, Jones JE. et al C-reactive protein as an aid in the differentiation of functional and inflammatory bowel disorders. Clin Chim Acta 1985;148:105-9.

23. Vermeire S, Van Assche G, Rutgeers P. Laboratory markers in IBD: Useful, magic, or unnecessary toys? Gut 2006;55:426-43. 


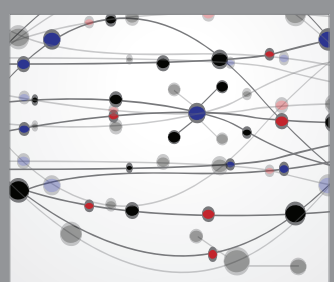

The Scientific World Journal
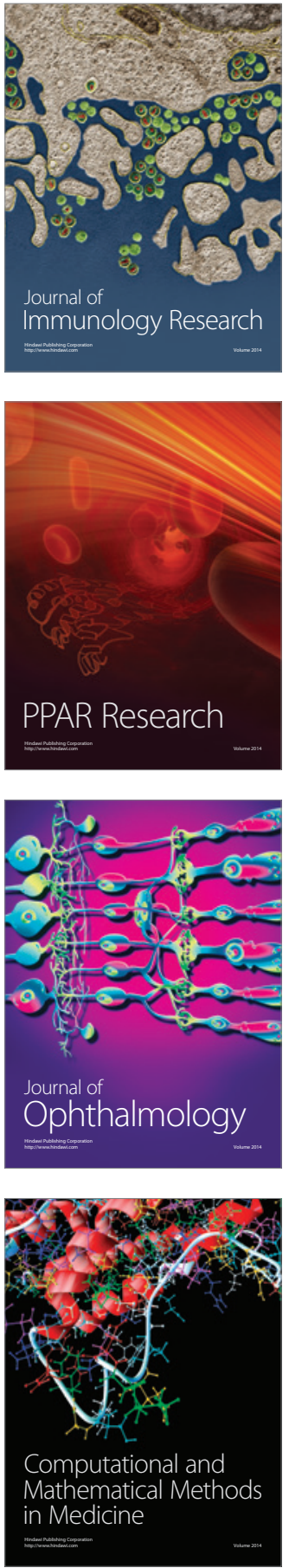

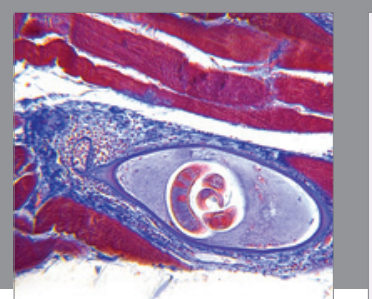

Gastroenterology Research and Practice

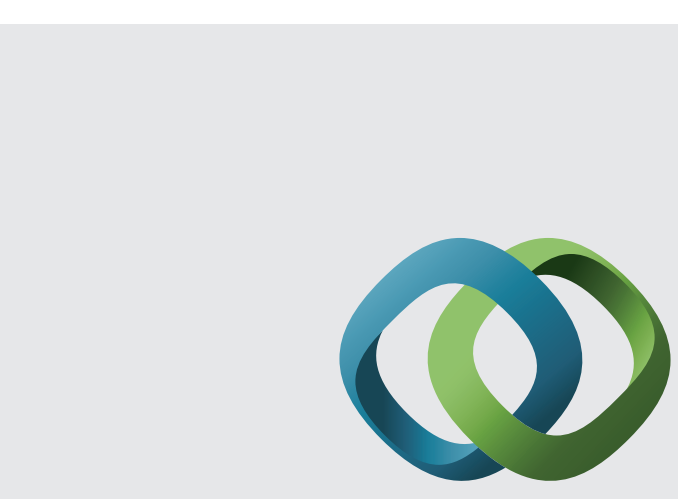

\section{Hindawi}

Submit your manuscripts at

http://www.hindawi.com
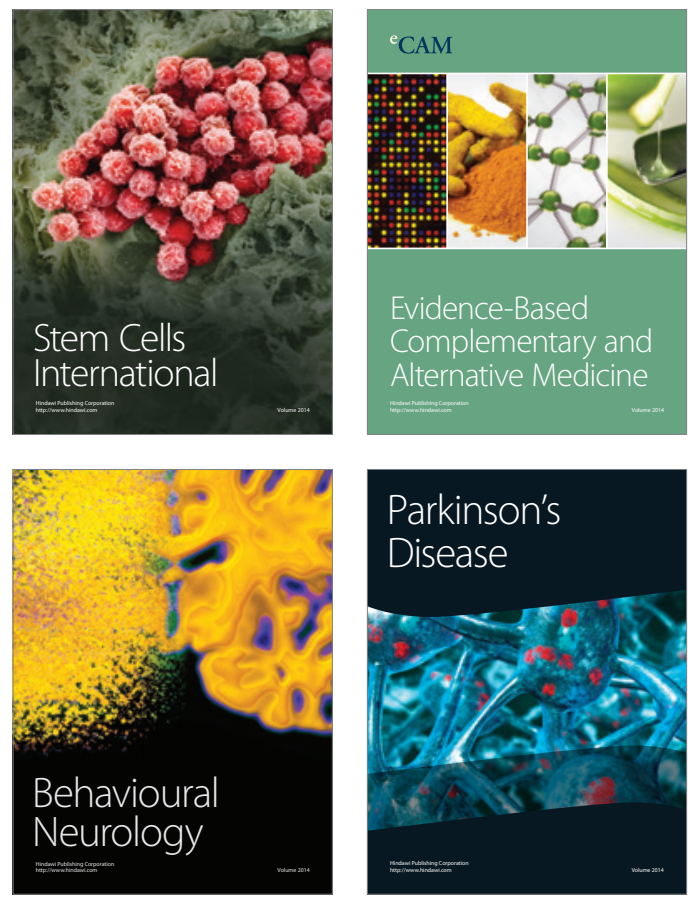
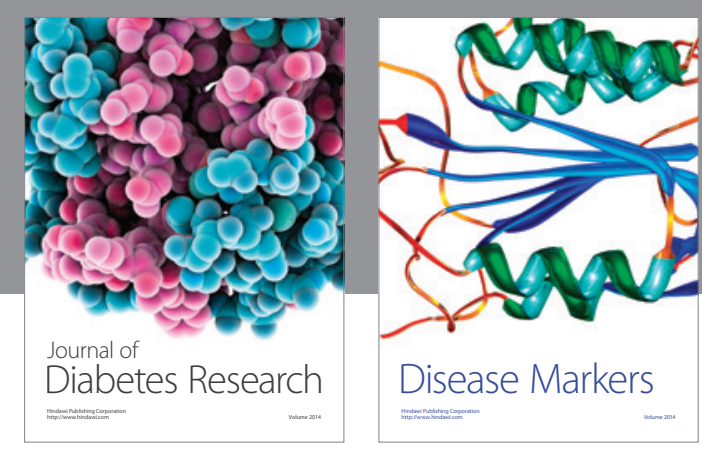

Disease Markers
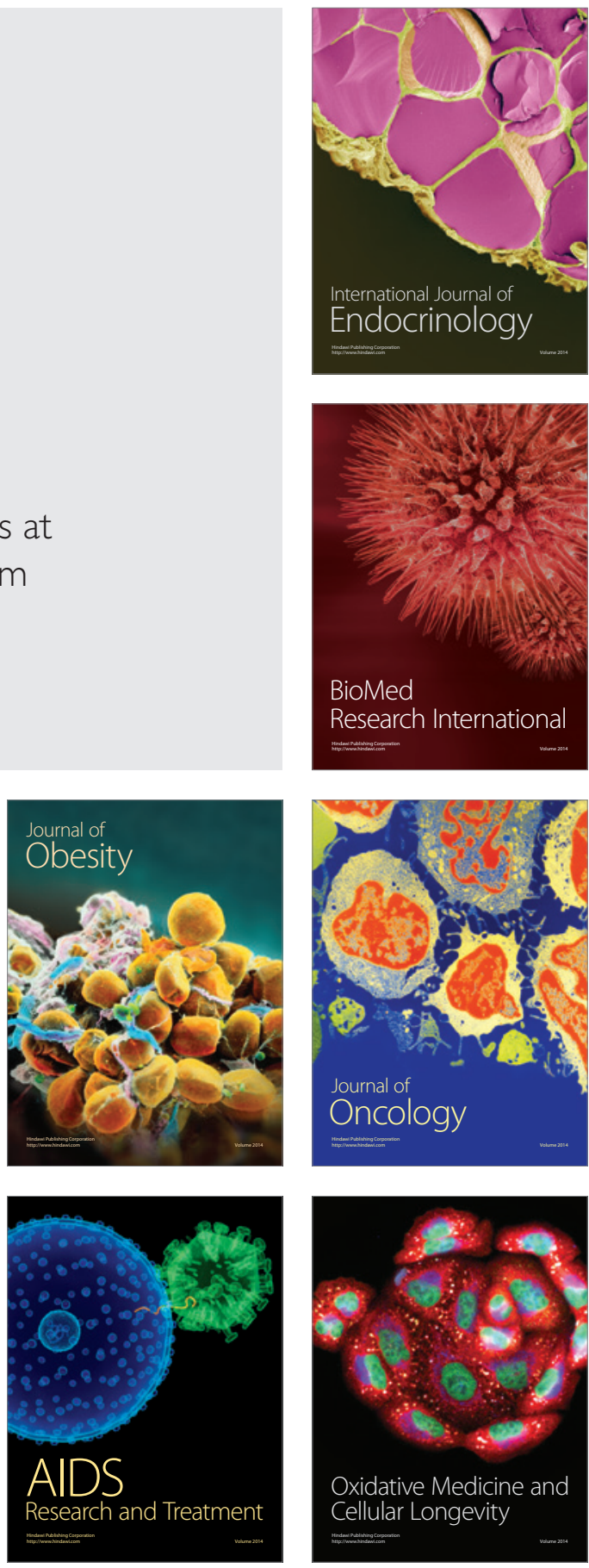